\title{
Is intravenous vitamin C contraindicated in patients with G6PD deficiency?
}

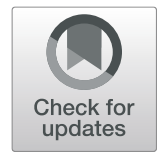

Paul E. Marik

Keywords: Vitamin C, G6PD deficiency, Sepsis, Septic shock, Clinical trials

There is increasing interest in the use of intravenous vitamin $C$ as adjunctive treatment in the management of patients with sepsis and septic shock. Currently, there are at least 20 randomized controlled trials worldwide testing this intervention in patients with sepsis. Almost all of these trials list glucose-6-phosphate dehydrogenase (G6PD) deficiency as an exclusion criterion. This is based on a handful of cases of hemolysis in patients with G6PD deficiency who received large pharmacologic doses of IV vitamin $\mathrm{C}(>60 \mathrm{~g})$ [1]. However, the reality is that low-moderate dose intravenous vitamin $\mathrm{C}$ may be the treatment of choice for drug-induced hemolysis in patients with G6PD deficiency. In vitro data dating back to 1979 has demonstrated that vitamin C in plasma concentrations up to $5 \mathrm{mmol} / \mathrm{l}$ inhibited the oxidation of oxyhemoglobin and Heinz body formation in G6PD-deficient red cells incubated with acetylphenylhydrazine (a strong oxidizing drug) [2]. Serum concentrations of vitamin C are typically in the range of 200-600 umol/l when dosed with $1.5 \mathrm{~g}$ IV q 6 hourly. Furthermore, case reports and case series have demonstrated a dramatic reduction of methemoglobinemia and hemolysis in patients treated with intravenous vitamin $C$ in a dose between 1 and $10 \mathrm{~g}$ q 6 hourly [3, 4]. Indeed, intravenous vitamin $C$ may be the treatment of choice in G6PD-deficient patients with drug-induced hemolysis, as methyl blue is contraindicated in these patients [3]. These data suggest that in the dosage currently under investigation ( $6 \mathrm{~g} /$ day), vitamin $C$ should not be considered contraindicated in patients with known or suspected G6PD deficiency. This is important, as GDPD deficiency is not uncommon in patients of African and Mediterranean descent [5]. Furthermore, sepsis per se may cause methemoglobinemia in both G6PD-deficient patients and those with normal G6PD function.

Correspondence: marikpe@evms.edu

Division of Pulmonary and Critical Care Medicine, Eastern Virginia Medical School, 825 Fairfax Av, Suite 410, Norfolk, VA 23507, USA

\author{
Acknowledgements \\ None. \\ Funding \\ None.
}

Availability of data and materials

Available on request.

\section{Author's contributions}

The author read and approved the final manuscript.

\section{Author's information}

Not applicable.

Ethics approval and consent to participate Not applicable.

\section{Consent for publication \\ The author has reviewed the final version of the manuscript and approves the manuscript for publication.}

\section{Competing interests}

The author declares that he has no competing interests.

\section{Publisher's Note}

Springer Nature remains neutral with regard to jurisdictional claims in published maps and institutional affiliations.

Received: 4 March 2019 Accepted: 18 March 2019

Published online: 03 April 2019

\section{References}

1. Campbell GD, Steinberg MH, Bower JD. Ascorbic acid-induced hemolysis in G-6-PD deficiency [Letter]. Ann Intern Med. 1975;82:810.

2. Winterbourn CC. Protection by ascorbate against acetylphenylhydrazineinduced Heinz body formation in glucose-6-phosphate dehydrogenase deficient erythrocytes. Br J Haematol. 1979;41:245-22.

3. Rehman A. Severe acute haemolytic anaemia associated with severe methaemoglobinaemia in a G6PD-deficient man. BMJ Case Reports. 2018; 2018:bcr-2017-223369.

4. Rino PB, Scolnik D, Fustinana A, Mitelpunkt A, Glatstein M. Ascorbic acid for the treatment of methemoglobinemia: the experience of a large tertiary care pediatric hospital. Am J Ther. 2014;21:240-3.

5. Maffi D, Pasquino MT, Mandarino L, Tortora P, Girelli G, Meo D. Glucose-6phosphate dehydrogenase deficiency in Italian blood donors: prevalence and molecular defect characterization. Vox Sang. 2014;106:227-33.

(c) The Author(s). 2019 Open Access This article is distributed under the terms of the Creative Commons Attribution 4.0 International License (http://creativecommons.org/licenses/by/4.0/), which permits unrestricted use, distribution, and reproduction in any medium, provided you give appropriate credit to the original author(s) and the source, provide a link to the Creative Commons license, and indicate if changes were made. The Creative Commons Public Domain Dedication waiver (http://creativecommons.org/publicdomain/zero/1.0/) applies to the data made available in this article, unless otherwise stated. 